\title{
CELESTINA'S BLACK MASS
}

\author{
Mac E. Barrick \\ Shippensburg State College
}

Immediately prior to the incantation scene (LC, III, 146-147, Cejador ed.), Celestina asks Elicia to bring her some items from "la cámara de los vngüentos," specifically "la sangre del cabrón e vas poquitas de las baruas, que tú le cortaste." Though these objects have been frequently discussed, their exact function at this juncture has not been established.

Both Cejador and Laza Palacios (LCDB, no. 58, p. 105) approach the matter without developing it. Each cites Gerónimo de Huerta's annotations on Pliny to the effect that goats are "entre todos los animales los más Iuxuriosos e incontinentes" and that they are "símbolos del demonio y de la mala mujer." Laza Palacios later ( $p$. 176) notes Laguna's commentary on Dioscorides: "La sangre del cabrón mentenido con apio, peregil e hinojo, bevida caliente, o dada con vino en polvo, deshaze la piedra de la vejiga. Dicen que el diamante, cuva fortaleza menosprecia todo fuego y acero, se dexa vencer de esta sangre, y echando en ella caliente y acabada de fluir de las venas, se ablanda." This latter belief, which derives ultimately from Pliny (Histoma Naturalis, XXXVII, 15, 59-60), was widespread through the Middle Ages and well into the seventeenth century, 1 and, though subsequently disproven by Montaigne, ${ }^{2}$ is the only feature of goat's blood mentioned in the imitations and continuations of LC. 3

P.E. Russell (LCDB, no. 302, p. 349) alludes to the use of "los objetos cabrunos" in the practice of love magic, and indeed other parts of. the goat are mentioned elsewhere as effective love charms. The Celestina of the Lisandro y Roselia advises Roselia: "Pues véte, amiga, y como te digo, para traerle á tu amor, úntale las manos con aquel sebo de cabrón, cuando entre burlas y véras se las tomares, y di estas palabras que te he dicho, que son muy aprobadas" (p. 86). And in the Comedia Florinea, Marcelia encloses "unos polvillos del cabrón" in a letter, "para que si Floriano ama a Belisea, y ella lee la carta, ella le ame a él, y si no quedarse ha libre; que al fin estas cosas sólo Dios las ha de saber" (NBAE, XII, 208). Yet, curiousIy, Pármeno mentions none of these, nor the scongre $y b c a b a$, in his listing of Celestina's materia cosmética and other items "para remediar amores." 4 This omission may be simply an 
oversight due to the change of authors, but more likely these materials are significantly different from those included in Pármeno's catalog. Since Pármeno cautiously qualified his listing ("todo era burla y mentira"5), these subsequent items might be considered intentionally not "burla y mentira." Their placement within the cómara de ungüentos inside a black cat skin underscores their unique purpose as magic objects, in contrast to the other paraphernalia with more mundane cosmetic or pharmaceutical uses. The herbs, drugs and other things in Celestina's collection were not included by the author merely to overwhelm the reader with a sense of horror and disgust. Each has been shown to be effective in the practice of folk medicine, witchcraft or popular psychology. So it is that the mention of these special materials at the incantation scene must be examined with reference to the author's intention.

The role of the male goat in the Witches' Sabbaths is well known.6 What is often overlooked is that these Sabbaths usually involved a ritual sacrifice, either of an innocent victim, of a witch or of the god (i.e., the goat) himself. When Celestina asks Elicia for the beard clippings "que tú le cortaste," she insinuates that the moza has participated in one of these rituals and has brought the objects in question. back with her. It is no accident that. Sancho de Muñón selects Elicia as the "digna herdera de Celestina" in his Tragicomedia de Liscandro y Roselia.

The utilization of hair, both corporal and facial, in the practice of magic has been commonly noted. The principle involved is that of contagion, that things once joined remain sympathetically attached, even though later separated and, that parts of a body, in this case hair, containing an essence of the whole, may be used to work an effect on that body as if they were still connected to it. Numerous examples might be cited, but a few from Celestina-literature will suffice: Elicia as the Celestina of Liscondro y Roselia prepares "a los amantes hechizos de cabello o cordón con que hagan que sus amigas les amen, y aborrezcan el que amaban, y amen el que aborrecían" (p. 73); Claudina in the Tragedia Policicana offers to perform a conjury for Silvanico if he will bring her "una gallina prieta de color de cuervo, e vn pedaço de la pierna de un puerco blanco, e tres cabellos suyos cortados martes de mañana antes que el sol salga" (acto XVI, p. 33); and of course, of the original Celestina Pármeno tells us that "venian a ella muchos hombres y mugeres, y a vnos demandaua el pan do mordian, a otros de su ropa, a otros de sus cabellos" (I, 44).7 Thus possession of these "barbas del cabrón" implies a magic power over the animal from which they came and over the Devil which he represents. Mention of this and similar objects by Lucas Fernánde ${ }^{8}$ suggests that the hairs may have been burned as a mock incense in sacrilegious rituals.

The use to which Celestina puts the blood of the goat during the incantation is not stated, but it can be surmised from contemporary references. Inquisition documents from the fourteenth to the eighteenth century describe the Witches's Sabbaths as Black Masses and blasphemous parodies of other Christian rituals. For example, one Ana María de Georgel, tried for witchcraft in Toulouse in the fourteenth century, stated that "el macho cabrío... le aconsejó que hiciera, si podía, 
comuniones sacrílegas para ofender a Dios y, en gloria del Diablo" (Caro Baroja, Las bmijas, pp. 115-116).9 Just as the Sabbaths were grotesque travesties of the Christian Mass, so Rojas makes his incantation scene a Black Mass in miniature with Celestina serving as her ow priest in a private diabolic communion. The blood of the goat-god has become for her the wine of the Sacrament, without need of transubstantiation, representing the blood of the Devil in his physical appearance at the Sabbaths. As a converso Rojas could not risk attracting to himself the medieval suspicion of the Jew as a Devil worshipper, 10 so he does not mention the ultimate utilization of the "objetos cabrunos," just as he avoids mention of Satan, hiding him instead under the name of Plutón (cf. Russell, p. 349). Whether one accepts or not the accelerating effect of magic on the developing amorous relationship between Calisto and Melibea, there can be no doubt that Celestina believed in and practiced magic, being indeed a witch within the Christian tradition.

\section{NOTES}

I TO H. D. Austin's bibliography in "An Inheritance of Magic," MLN, 60 (1945), 324-325, add The Book of Beasts, tr. T. H. White (New York, 1954), p. 75, and Pseudo-Aristotle, Poridat de Zas poridades, ed. Lloyd A. Kasten (Madrid, 1957), p. 74.

${ }^{2}$ See Robert D. Cottrell, "Of Dialectics and Goat's Blood in an Anecdote by Montaigne," RenQ, 30 (1977), 29-42.

3Sancho de Muñón, Liscondro y Roselia (Madrid, 1872), p. 9; Pedro Hurtado de la Vera, La Doleria, NBAE, XII, 354. The belief is mentioned also in Quevedo's Buscón (II, vi) and in Góngora's "Angélica y Medoro" (vv. 25-28).

${ }^{4}$ Rodrigo de Reinosa includes "sangre del cabrón" among the objects used by Mari-García to "hacer hechizos y cosas para bien querer" (ed. J. M. de Cossío [Santander, 1950], p. 64), and Agustín de Rojas Villandrano speaks in his Viaje entretenido (ed. J. P. Ressot [Madrid, 1972], p. 103), of an hechicera who used, among other things, "sangre y barba de cabrón bermejo, sesos de asno, y una redomilla de aceite serpentino," for which she was subsequently punished for witchcraft.

5There are two interpretations of the phrase: (1) that the original author, being careful to avoid trouble with the Inquisition, dismisses these items as innocuous; and (2) that the phrase is a reference to the orthodox medieval doctrine denying supernatural powers to witches (Russell, art. cit.). As has been shown elsewhere (Barrick, LCDB, no. 82 , p. 387, n. 19), such disclaimers are not unusual in Spanish literature.

${ }^{6}$ See Margaret Murray, The Witch-Cult in Western Europe (Oxford, 1921), pp. 68-69, 97-112; Montague Summers, The History of Witchcraft and Demonology (New York, 1926), ch. 4, esp. pp. 134-136; Julio Caro Baroja, Las brujas y su mondo (Madrid, 1968), pp. 115-120. 
The belief is mentioned also in Apuleius' Golden Ass (ch. 4) and appears frequently in dramatic literature (see Pavia, LCDB, no. 112, pp. 41, 57-59; cf. Reinosa, p. 63).

8"Sabe hacer bollo maimon, / Y hace asbondo zahumerios / De las barbas del cabron" (Farsas y églogas [Madrid, 1867], pp. 149-150).

${ }^{9} \mathrm{Cf}$. descriptions of such Masses and the articles used as Sacraments in Summers, pp. 144-157, and Murray, p. 150.

${ }^{10}$ See Venetia Newall, "The Jew as a Witch Figure," in The Witch Figure. (London, 1973), pp. 95-124, esp. 108-111. Cf. Fernando ToroGarland, $L C D B$, no. 376 , p. 444.
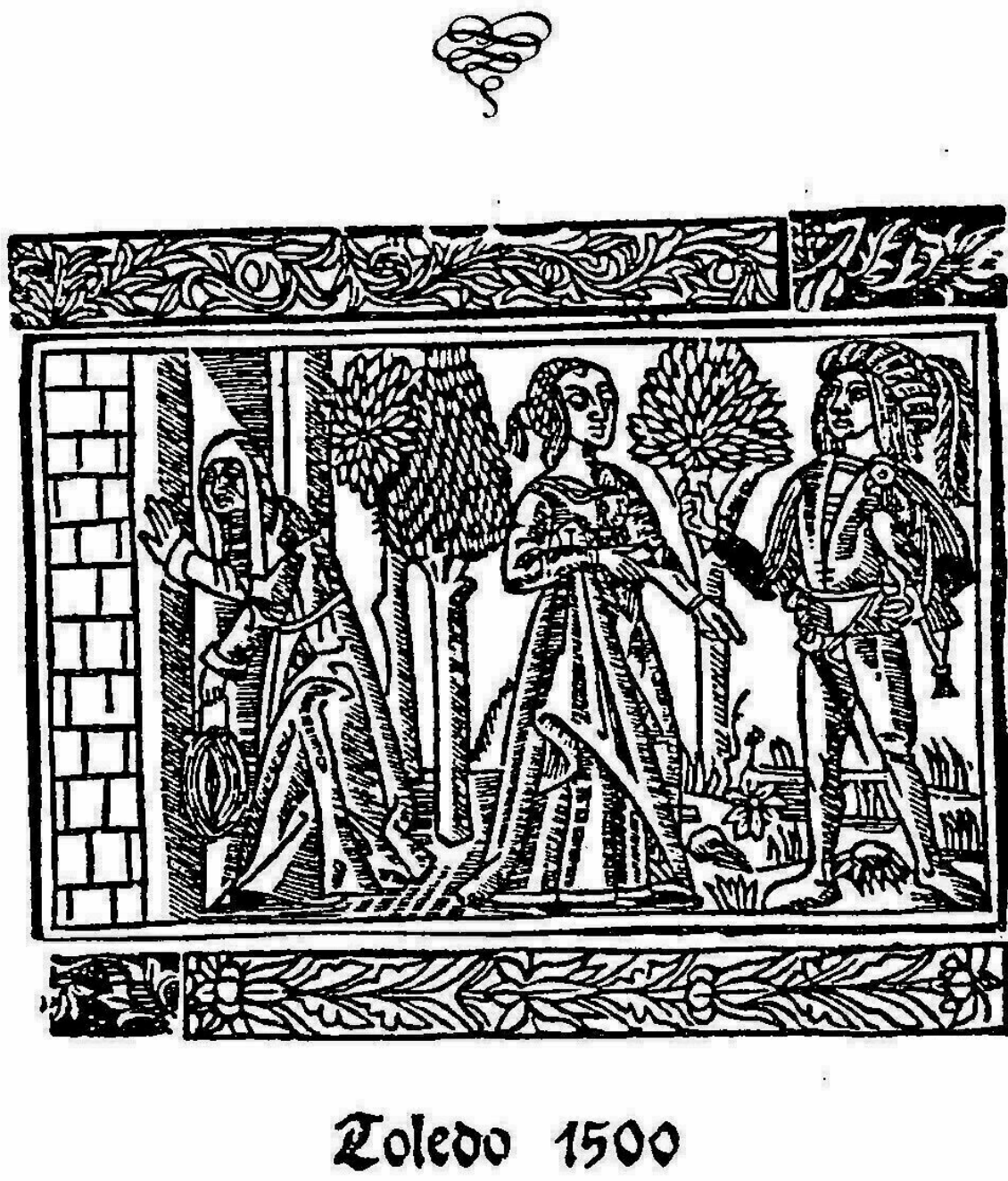